\title{
BIODISTANCES AMONG MEXICA, MAYA, TOLTEC, AND TOTONAC GROUPS OF CENTRAL AND COASTAL MEXICO
}

\author{
LAS DISTANCIAS BIOLÓGICAS ENTRE LOS MEXICAS, MAYAS, TOLTECAS, \\ Y TOTONACAS DE MÉXICO CENTRAL Y ZONA COSTERA
}

\author{
Cathy Willermet ${ }^{1}$, Heather J.H. Edgar ${ }^{2}$, Corey Ragsdale ${ }^{2}$ and B. Scott Aubry ${ }^{3}$
}

\begin{abstract}
Migration patterns in pre-European contact Mexico were complex. Studies using dental morphological data have successfully detected microevolutionary patterns of biological affinity between local populations in other areas of the world. We compare Classic and Postclassic dental samples from four cultural groups from adjacent regions in Mexico to illuminate local population differences among the Toltecs, Mexica, Totonacs, and Maya. We calculated pseudo Mahalanobis $\mathrm{D}^{2}$ distances using observations of 12 dental traits to compare models for how culture group, geography, and time may have structured interpopulation relationships. Cluster analysis and principal components analyses of pairwise population distances suggest that phenetic similarities best reflect differences among cultural groups. Additionally, dental morphological trait data are robust with regard to interobserver error and sensitive enough to detect phenetic distance over relatively small time and space dimensions in Mexico. These results encourage expanding the study to more sites, regions, and temporal periods, and augurs well for future investigations that seek to trace past migration patterns in Mexico.
\end{abstract}

Key words: Biological distance, pre-European contact Mexico, dental morphological traits.

En México, los patrones de migración previos al contacto con los europeos eran complejos. Los estudios que utilizan datos morfológicos dentales han logrado detectar exitosamente micropatrones evolutivos de afinidad biológica entre las poblaciones locales y aquellas en otras zonas del mundo. Comparamos muestras dentales de los períodos Clásico y Postclásico de cuatro grupos culturales de las regiones adyacentes a México para ilustrar las diferencias locales entre los toltecas, los mexicas, los totonacas, y los mayas. Hemos calculado las seudodistancias de Mahalanobis $D^{2}$ utilizando observaciones de 12 rasgos dentales para comparar los modelos basados en el grupo cultural, la geografía y el tiempo que puede haber estructurado relaciones entre dichas poblaciones. Los análisis estadísticos multivariados de agrupación (cluster) y de componentes principales sobre las distancias entre pares de poblaciones sugieren que las similitudes fenéticas reflejan mejor las diferencias entre los grupos culturales. Asimismo, la información de los rasgos morfológicos dentales son fuertes respecto del error del interobservador y lo suficientemente sensibles para detectar la distancia fenética sobre el tiempo y dimensiones espaciales relativamente pequeñas en México. Estos resultados fomentan ampliar el estudio a más lugares, regiones y períodos temporales, y son un buen augurio para futuras investigaciones que tratan de rastrear los patrones de migración del pasado ocurridos en México.

Palabras claves: distancia biológica, precontacto europeo-México, características morfológicas dentales.

Human migration patterns in pre-European contact Mexico are thought to have been complex, for widespread trade was common, and individuals and small groups likely moved between the northern drylands, central highlands, and coastal lowlands (De Lourdes Muñoz et al. 2012; Diehl 2000; Hammond 2000; Lopéz Austin and Lopéz Luján 2001). Our knowledge of precontact population relationships is informed by a vast archaeological record, from the smallest grains of pollen from traded plants, to cultural influences evident in architectural details of major cities. Additionally, in Mesoamerica, at least four indigenous cultures developed written historical traditions: the Maya, Zapotec, Mixtec, and Nahuatl (Marcus 1976). This rich and complex ethnohistorical and archaeological record means detailed information about ethnicity and migrations is available from many sources that sometimes conflict (Stark and Arnold 1997). This intricate record of local, regional, and long-distance migrations, coupled with shifting political power, interregional elite relationships, and periods of centralization/

1 Department of Sociology, Anthropology, and Social Work, Central Michigan University, Mt. Pleasant, MI 48859 U.S.A. Corresponding author: wille2cm@cmich.edu

2 Maxwell Museum of Anthropology and Department of Anthropology, University of New Mexico, Albuquerque, NM 87131, U.S.A. hjhedgar@unm.edu; ragsdalc@unm.edu

3 Department of Anthropology, The Ohio State University-Newark, Newark, OH 43055, U.S.A. aubry.8@ osu.edu 
decentralization has led some to claim that tracing small-scale pre-contact Mexican population structure may be impossible using archaeological methods (Davies 1980; Evans 2013; Schortman and Urban 2001). However, local population movements might be detectable using biological data.

In studies of Mesoamerican samples, dental morphological trait analyses have focused primarily on descriptive or intraregion analysis, rather than broader interregional comparisons (e.g., Cucina and Tiesler 2004; Haydenblit 1996; Pompa y Padilla 1984, 1990, 1996; Scherer 2004; Wrobel 2003). Recently, biodistance studies using dental morphological traits have been performed on closely related cultural groups in several world areas (e.g., Aubry 2009; Ullinger et al. 2005; Vargiu et al. 2009) indicating they are of sufficient sensitivity to detect population differences developed over relatively short time spans.

To illuminate local population differences, we compare samples from sites associated with four different cultural groups located in adjacent regions of Mexico: the Toltecs and Mexicas from Central Mexico; the Totonacs from the Gulf Coast lowlands of Veracruz; and the Maya from the northern lowlands of the Yucatan Peninsula. Populations of these four regional cultural entities were in contact with one another through military actions and longdistance trading (Evans 2013). Nevertheless, these groups were culturally and linguistically distinct, and contemporary accounts describe them as physically distinctive as well (Berdan 2008; Diehl 2000; Weaver 1972). In the current study, we perform a biodistance analysis using dental morphological traits to illuminate any biological patterning among the groups. Samples come from the following sites: Cholula, Puebla; El Zapotal, Veracruz; Jaina Island, Campeche; San Gervasio/Playa del Carmen, Quintana Roo; Tlatelolco, Mexico City, D.F.; Tula, Hidalgo; Yaxuna, Yucatan.

\section{Sources of Population Structure}

We predict that the four groups in this study, while similar in many respects, are sufficiently distinct to be distinguished through biodistance analysis. Given the complexity of the archaeological and ethnohistorical accounts of population movements and relationships, several possible patterns of biological relationships may be formulated. We examine three factors that could structure the relationships among these samples - cultural group, geographic region, and temporal period.

\section{Cultural groups}

The Maya. The lowland Maya emigrated from the Guatamalan highlands by $1000 \mathrm{BC}$ at the latest (Campbell and Kaufman 1985; Colunga-García Marín and Zizumbo-Villarreal 2004; Hammond 1986; Pohl et al. 1996; Weaver 1972). In the Classic Period, local and regional political control became increasingly concentrated into larger centers (Evans 2013). By the Terminal Classic, the political and population landscape shifted to the northern and coastal peninsular lowlands (Aubry 2009; Masson and Mock 2004). Sites like Uxmal and Chichén Iztá rose in prominence, in part through expansion of circum-peninsular maritime trade networks (Evans 2013; Masson and Mock 2004).

Trading relationships, and likely migration, existed between the Maya and other regional polities, such as Teotihuacan, Tula, and Cholula (Aubry 2009; Cowgill 2003; Culbert 1991). Long-distance gene flow has been detected within the Maya (Scherer 2007), and Teotihuacan and Mayan elites may have practiced bride exchange (Schroeder 2010). Connections between the Maya and Toltecs, who spread to regions like the Yucatan after the fall of Tula may have influenced the development of Yucatan sites such as Chichén Itzá (Davies 1980; Diehl 1983; McVicker 1985; but see Jones 1997). Mayan samples in this analysis come from the sites of Jaina Island, San Gervasio/Playa del Carmen, and Yaxuna.

The Toltecs. The Toltecs were Nahuatl/Otomí speakers who rose to power after the fall of Teotihuacan around AD 750. Their origin is unclear; they may have migrated from northwest of Jalisco, Veracruz, or Michoacán (Evans 2013). They were said to reside in the mythical city of Tollan, usually identified as Tula Hidalgo (Brotherston 2001; Cowgill 2000; Davies 1980; Diehl 1983). The Toltecs participated in widespread trade networks and extended influence throughout Mesoamerica (Davies 1987; Weaver 1993). They were known for military prowess, and conquered and exacted tribute through forceful action. Mexica and Maya elites later legitimized their rule by claiming descent from Toltec royal bloodlines (Cobean and Mastache 2001; Hicks 2008; Smith 1984, 2008). 
Toltec rule declined and Tula was abandoned in the mid- $12^{\text {th }}$ century AD. The Toltecs settled in many regions outside of Central Mexico, into the Gulf Coast, the Yucatan peninsula and highland Guatemala (Diehl 1983). Toltec-style art and architecture are present in later Classic and Postclassic Yucatan Maya sites such as Chichén Itzá (Davies 1980; Diehl 1983; McVicker 1985). It is possible that the Maya and Toltec relationships might be closer to one another than to other groups due to long-term contact (Aubry 2009; De Lourdes Muñoz et al. 2012). Samples from the Toltec sites of Tula and Cholula are included in this analysis.

The Mexica. The Aztec Mexica were the last of several Nahuatl-speaking Aztlan populations migrating to Central Mexico from the north (Smith 1984). It is likely that Nahuatl was one of the languages spoken in Toltec cities, brought south from previous ethnic Aztlan migrations (Davies 1980; Evans 2013). The Mexica arrived in the Valley of Mexico in the mid- $13^{\text {th }}$ century, and encountered the remnants of the Toltec empire (Hicks 2008; Weaver 1972). The Toltec elites were still considered "noble blood;" claiming noble Toltec family ties through marriage granted civilized status and political legitimacy in Aztlan society (Hicks 2008; Smith 1984, 2008). The Mexica accomplished their political dominance through strategic intermarriage with Toltec nobles and by conquering local cities, leaving defeated kings in power to send tribute to the capital city of Tenochtitlan. The Mexica maintained political control through exaggerated ritual violence and large-scale human sacrifice (Lopéz Austin and Lopéz Luján 2008). The Mexica formed the "Triple Alliance" with two other Aztlan ethnic groups (Evans 2013). Within a few generations of founding Tenochtitlan, the Mexica dominated the political landscape in Central Mexico until the Spanish arrived in AD 1519 (Hicks 2008). The Mexica sample comes from the site of Tlatelolco.

The Totonacs. The Totonacs settled in the South-central Gulf lowlands around AD 600. The Totonac language shares similarities with Nahuatl and Mayan languages (Campbell 2004; Lewis 2009). It is not known from where the Totonacs emigrated, although some may have moved to coastal Veracruz from inland cities to avoid direct conflict with early migrations of Aztlan peoples (Weaver 1972). Archaeological evidence at sites such as Totonacapan suggests that the region was densely settled. Ceramics include both Totonac and Mixteca-Puebla styles seen in Central Mexican sites such as Tlaxcala, located on the other side of the Sierra Madre mountain range (Daneels 1997). This suggests widespread trade between coastal and inland sites (Ochoa 2001; Stark 1978) and perhaps an ethnically mixed site (Daneels 1997).

This Totonacapan region of the Gulf coast was reliably fertile, and Aztlan called it the "land of food" (Evans 2013:443). During droughts and famines, such as in AD 1450-1454, some Aztlan families sold themselves or their children as slaves to the Totonac (Diehl 2000; Evans 2013; Weaver 1972). Many Totonac cities were subdued by the Triple Alliance until the arrival of Cortés in AD 1519, when they became the first allies of the invaders (Diehl 2000; Hassig 2010). The Totonac sample comes from the site of El Zapotal.

\section{Geographic regions}

The sites in this analysis are in three distinct regions: Central Mexico, Veracruz, and the Yucatan (Figure 1). Geographic locations for each site were obtained using Global Positioning System coordinates. Land distances between sites were calculated using Google Earth version 6 (Google Earth 2012), estimating the shortest possible land route, accounting for natural geographic barriers (Tables 1 and 2).

Central Mexico. The central highlands of Mexico sit between the parallel northwest/southeast ranges of the Sierra Madre Occidental and Oriental, and bounded on the south by the snowcapped volcanos Iztaccíhuatl and Popocatépetl. These three ranges create a temperate highland region with seasonal rainfall. The Basin of Mexico is a broad interior mountain valley that traps water into Lake Texcoco, a wide, shallow, moderately salty interior lake with an extensive river valley system (Cowgill 2000; Grove 2000). The sites used in this analysis in this region include Tlatelolco, Tula, and Cholula (see Table 1 for site information).

Veracruz. The Gulf Coast is bounded on the west by the Sierra Madre Orientale range, and on the east by the Gulf of Mexico. The Gulf Coast is diverse in altitude, drainage, and precipitation. It is traditionally divided into three regions bordered by 


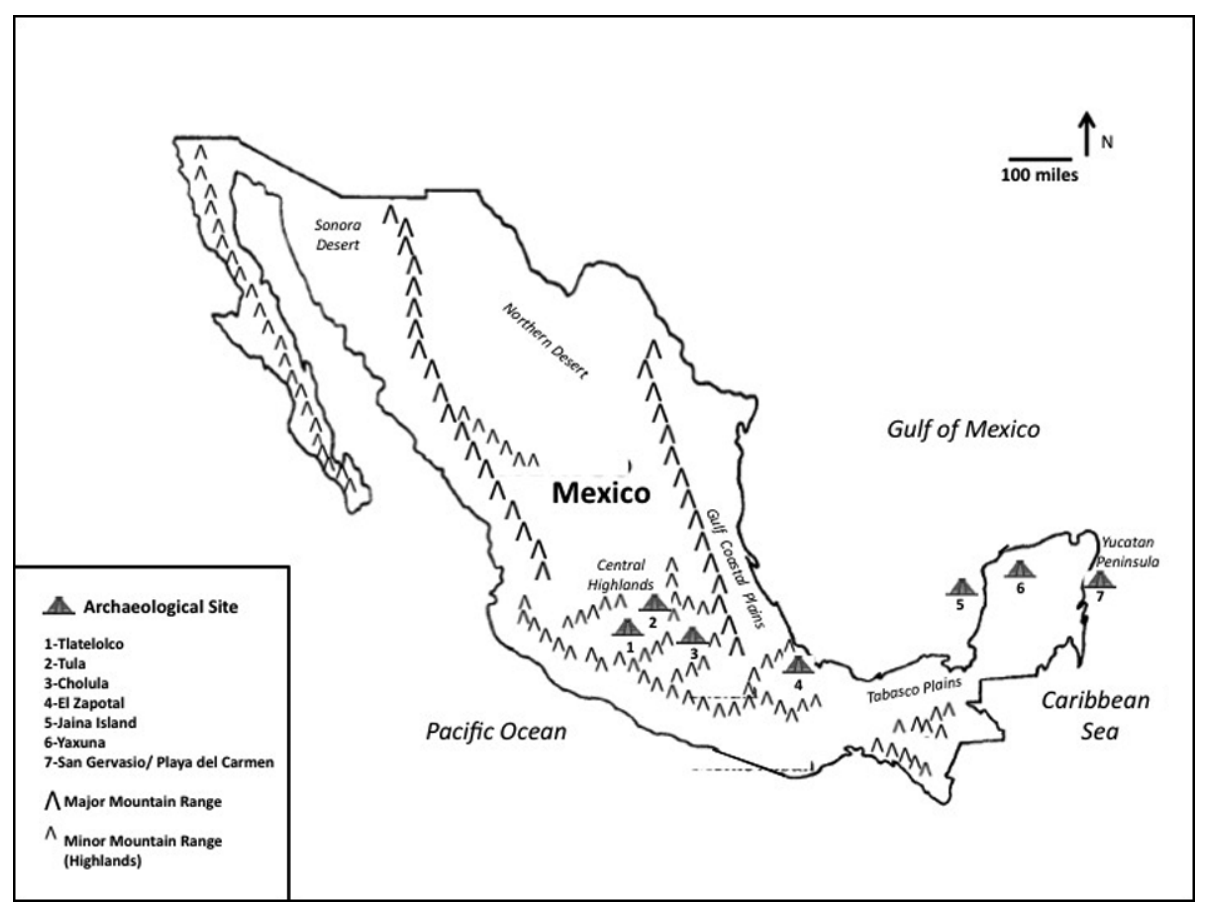

Figure 1. Map of sites used in this study.

Mapa de sitios utilizados en este estudio.

Table 1. Samples used in this study. Muestras utilizadas en este estudio.

\begin{tabular}{|c|c|c|c|c|}
\hline Site & Culture group & Location & Temporal period & $\mathrm{N}$ \\
\hline Cholula & Toltec & Central Mexico & Classic & 50 \\
\hline El Zapotal & Totonac & Veracruz & Classic & 41 \\
\hline Jaina & Lowland Maya & Yucatan Peninsula & Postclassic & 23 \\
\hline $\begin{array}{l}\text { San Gervasio/ Playa del } \\
\text { Carmen }\end{array}$ & Lowland Maya & Yucatan Peninsula & Postclassic & 26 \\
\hline Tlatelolco & Mexica & Central Mexico & Postclassic & 73 \\
\hline Tula & Toltec & Central Mexico & Classic & 46 \\
\hline Yaxuna & Lowland Maya & Yucatan Peninsula & Classic & 23 \\
\hline
\end{tabular}

Table 2. Geographic land distances calculated between sites, in km. Distancias calculadas de la tierra geográfica entre sitios, en kilómetros.

\begin{tabular}{lrrrrrrr}
\hline & Tlatelolco & Tula & Cholula & El Zapotal & Jaina Island & Yaxuna & $\begin{array}{c}\text { San Gervasio/ Playa } \\
\text { del Carmen }\end{array}$ \\
\hline Tlatelolco & 0 & & & & & & \\
Tula & 91 & 0 & & & & & \\
Cholula & 112 & 192 & 0 & & & & \\
El Zapotal & 480 & 773 & 368 & 0 & & \\
Jaina Island & 848 & 1293 & 736 & 368 & 0 & & \\
Yaxuna & 1136 & 1259 & 1024 & 656 & 288 & 0 & \\
San Gervasio/ & 1628 & 1672 & 1517 & 921 & 509 & 208 & \\
Playa del Carmen & & & & & & & \\
\hline
\end{tabular}


mountains spanning central Veracruz to the coast. El Zapotal is in the central region, comprised of tropical forest with high rainfall, streams, rivers, and floodplains (Diehl 2000).

Yucatan. The Yucatan Peninsula is geographically diverse, from the southern highlands near Guatemala to the coastal lowlands in the north. Two of the three sites in this study are on the northwestern coastal region of the peninsula; the third is in the center of the peninsula, in the northern lowlands (López Austin and López Luján 2001). This portion of the peninsula is a flat limestone plain near sea level in the north, rising slowly inland. The northern region is seasonal and dry, with thin soil and scrub forest. The three sites representing this region include Jaina Island, San Gervasio/Playa del Carmen, and Yaxuna.

\section{Temporal periods}

Pre-contact Mesoamerica historically has been divided into the Preclassic (2500 BC-AD 300), Classic (AD 300-900), and Postclassic (AD 900-1520) periods (López Austin and López Luján 2001). The samples from this study derive from the latter two periods.

Classic period, $A D$ 300-900. During the Classic period, increased social and economic stratification concentrated power with elites, and there was a rise of urban centers and more intensive agricultural practices in rural areas. Long-distance trade was organized and controlled by regional capital cities such as Tula, Cholula, and Uxmal. In the Classic period, the Veracruz and coastal Yucatan sites were involved with interregional trade with Central Mexican sites such as Teotihuacan (López Austin and López Luján 2001).

Postclassic period, AD 900-1521. The Postclassic period was marked by political instability in many regions, increased warfare, intensified long distance trade, and widespread tribute from conquered groups to political leaders. During the latter part of this period, the Mexica rose to dominate much of Mesoamerica (López Austin and López Luján 2001). The Postclassic ended with Spanish conquest.

\section{Materials and Methods}

\section{Samples}

We analyzed dental morphological trait data on samples from seven sites. Edgar collected data for the sites of Tlatelolco, El Zapotal, and Jaina Island (see Table 1). Aubry (2009) provided data from the sites of Cholula, Tula, San Gervasio/Playa del Carmen, and Yaxuna. A total of 282 specimens were included in the study.

\section{Observational methods}

Dental morphology is an effective method for tracing intrapopulation variation, interpopulation relationships, and microevolution (Coppa et al. 1998; Dahlberg 1951; Edgar 2007; Greenberg et al. 1986; Hanihara 1967; Hillson 1996; Irish 2005; Jackes et al. 2001; Larsen 1997; Lukacs and Hemphill 1991; Scott 1973; Scott and Turner 1997; Turner 1987, 1990, 1992; Willermet and Edgar 2009). Dental morphological studies analyze data from observations of standardized morphological characteristics found on the crown surfaces of teeth, such as shovel shaped incisors and Carabelli's trait (Scott and Turner 1988; Turner et al. 1991). Tooth morphology is largely under genetic control, and is less affected by environmental factors than many other tissue systems (Larsen and Kelley 1991; Scott and Turner 1997). Also, information gathered from teeth can be compared across space and time, a benefit difficult to replicate using DNA or blood group studies (Irish 1993; Scott and Turner 1997). Dental nonmetric traits have a high genetic component in trait expression, are evolutionarily conservative, and are comparable through time, making them ideal for use in admixture studies, and powerful for exploring regional patterns of biological distance (Irish 2005; Scott 1973; Scott and Turner 1997).

Trait selection. Analysis began with 30 trait observations scored in common in data separately collected by Edgar and Aubry (2009). We then removed all traits expressing no variation (either $100 \%$ or $0 \%$ in the combined sample), showed high initial interobserver error, or for which tetrachoric 
Table 3. Dental traits used in this analysis, with breakpoints, number of observations, and frequencies. Rasgos dentales utilizados en este análisis, con puntos de interrupción, número de observaciones y frecuencias.

\begin{tabular}{|c|c|c|c|c|c|c|c|c|c|c|c|c|c|c|c|c|}
\hline \multirow{2}{*}{ Trait } & \multirow{2}{*}{-} & \multirow{2}{*}{+} & \multicolumn{2}{|c|}{$\mathrm{CH}$} & \multicolumn{2}{|c|}{$\mathrm{EZ}$} & \multicolumn{2}{|c|}{ JA } & \multicolumn{2}{|c|}{ SG } & \multicolumn{2}{|c|}{$\mathrm{TL}$} & \multicolumn{2}{|c|}{ TU } & \multicolumn{2}{|c|}{ YX } \\
\hline & & & $\mathrm{N}$ & $\%$ & $\mathrm{~N}$ & $\%$ & $\mathrm{~N}$ & $\%$ & $\mathrm{~N}$ & $\%$ & $\mathrm{~N}$ & $\%$ & $\mathrm{~N}$ & $\%$ & $\mathrm{~N}$ & $\%$ \\
\hline UI2SS & $0-2$ & $3-7$ & 41 & 0.95 & 15 & 0.93 & 14 & 0.79 & 8 & 0.75 & 44 & 0.86 & 23 & 0.87 & 16 & 0.94 \\
\hline UI2DS & $0-1$ & $2-6$ & 43 & 0.49 & 13 & 0.38 & 9 & 0.22 & 8 & 0.75 & 44 & 0.64 & 23 & 0.65 & 12 & 0.83 \\
\hline UI2IG & 0 & $1-4$ & 41 & 0.20 & 14 & 0.29 & 13 & 0.23 & 9 & 1.00 & 44 & 0.41 & 23 & 0.17 & 16 & 0.25 \\
\hline UM1CB & 0 & $1-7$ & 30 & 0.77 & 20 & 0.65 & 20 & 0.75 & 12 & 0.25 & 48 & 0.77 & 18 & 0.78 & 17 & 0.59 \\
\hline UM1C5 & 0 & $1-5$ & 29 & 0.41 & 23 & 0.30 & 18 & 0.61 & 13 & 0.00 & 49 & 0.49 & 15 & 0.27 & 17 & 0.24 \\
\hline UM1MC & $0-4$ & $5-6$ & 47 & 0.66 & 25 & 0.64 & 20 & 0.70 & 13 & 0.62 & 54 & 0.69 & 26 & 0.81 & 19 & 0.68 \\
\hline $\mathrm{UM} 2 \mathrm{HC}$ & $0-1$ & $2-6$ & 46 & 0.93 & 24 & 0.75 & 15 & 0.80 & 11 & 0.91 & 52 & 0.81 & 27 & 0.96 & 17 & 0.76 \\
\hline UM2MC & $0-3$ & $4-6$ & 45 & 0.84 & 26 & 0.92 & 18 & 0.89 & 11 & 0.09 & 53 & 0.85 & 26 & 0.96 & 17 & 0.82 \\
\hline LM1C7 & 0 & $1-4$ & 40 & 0.20 & 21 & 0.19 & 12 & 0.25 & 12 & 0.50 & 58 & 0.16 & 23 & 0.30 & 16 & 0.44 \\
\hline LM1PS & 0 & $1-7$ & 44 & 0.05 & 20 & 0.40 & 11 & 0.55 & 16 & 0.25 & 55 & 0.62 & 25 & 0.08 & 15 & 0.07 \\
\hline LM1MT & 0 & 1 & 29 & 0.07 & 18 & 0.56 & 12 & 0.08 & 14 & 0.14 & 49 & 0.16 & 17 & 0.06 & 11 & 0.18 \\
\hline LM2PS & 0 & $1-7$ & 42 & 0.07 & 20 & 0.35 & 9 & 0.44 & 15 & 0.13 & 55 & 0.49 & 25 & 0.08 & 14 & 0.07 \\
\hline
\end{tabular}

UI2SS: maxillary second incisor, shoveling; UI2DS: maxillary second incisor, double shoveling; UI2IG: maxillary second incisor, interruption groove; UM1CB: maxillary first molar, Carabelli's trait; UM1C5: maxillary first molar, cusp 5; UM1MC: maxillary first molar, metacone; UM2HC: maxillary second molar, hypocone; UM2MC: maxillary second molar, metacone; LM1C7: mandibular first molar, cusp 7; LM1PS: mandibular first molar, protostylid; LM1MT: mandibular first molar, trigonid crest; LM2PS: mandibular second molar, protostylid. CH: Cholula; EZ: El Zapotal; JA: Jaina Island; SG: San Gervasio/Playa del Carmen; TL: Tlatelolco; TU: Tula; YX: Yaxuna.

correlations could not be computed due to zero denominators. After these processes 12 observations remained.

Determination of trait breakpoints. Calculation of pseudo Mahalanobis' $\mathrm{D}^{2}$ requires that data be in presence/absence format. We initially examined the raw data for evidence of natural breakpoints and used them when encountered. Additional breakpoints were drawn primarily from Scott and Turner (1997), with additional reference to Haeussler et al. (1989), Irish (1993), Irish and Turner (1990), and Turner (1987) (Table 3).

Interobserver error. Edgar and Aubry collected data and performed an interobserver error test using 11 of the above 12 traits on 30 dental models that were not part of this study. Dental models allow observers to study the same dentitions in two locations. Because dental models were used, interruption groove (UI2IG) was not scored. Using an online kappa calculator, we computed Cohen's kappa and associated standard error values, as well as the frequency of observer agreement for the dichotomized data (GraphPad Software 2005; see Table 4). Interobserver error levels were acceptable for both the nondichotomized and dichotomized data for most traits. To determine whether interobserver error would influence the results, we computed a one-way ANOVA using SPSS version 17 (2008), comparing the two observer's means by trait. Only two traits differed significantly: LM1PS $(p=0.00)$ and LM2PS $(p=0.04)$. This result was expected: LM1PS showed the lowest frequency of agreement (0.52), and LM2PS was not variable for one of the two observers. To understand whether interobserver error affected our results, we performed the Mahalanobis' distance analysis with and without U12IG and LM1PS. Both analyses achieved similar results. Therefore, we proceeded with the 12 traits listed in Table 3; see the Results section below for further interobserver analysis (Table 4).

Missing data. Statistical analysis and interpretation of results are complicated by the fact that sample sizes for several of the sites are small, and some data could not be collected due to incomplete preservation. The highest percent of observable data for a trait at any one site is 95\% (Cholula: UM1MC) and the lowest is $32 \%$ (El Zapotal: UI2DS). The average percent observable data across all sites is $60 \%$. Small sample sizes and missing data are inherent problems in bioarchaeological research, and limit the degree of assurance that researchers can have in the validity of their results. 
Table 4. Average difference, Cohen's kappa and associated standard error, and percent observer agreement for inter-observer error tests.

Diferencia promedio, kappa de Cohen y error estándar asociado y por ciento, observado para las pruebas de error por interobservador.

\begin{tabular}{|c|c|c|c|c|}
\hline \multirow[t]{2}{*}{ Trait } & \multirow{2}{*}{$\frac{\text { Raw data }}{\text { Average difference }}$} & \multicolumn{3}{|c|}{ Dichotomized data } \\
\hline & & $k$ & SE & Percent agreement \\
\hline UI2SS & 0.86 & 0.517 & 0.211 & $86 \%$ \\
\hline UI2DS & 0.59 & 0.372 & 0.197 & $85 \%$ \\
\hline UM1CB & 0.57 & 0.731 & 0.141 & $89 \%$ \\
\hline UM1C5 & 0.55 & 0.253 & 0.177 & $66 \%$ \\
\hline UM1MC & 0.34 & 0.041 & 0.191 & $72 \%$ \\
\hline $\mathrm{UM} 2 \mathrm{HC}$ & 0.24 & 0.610 & 0.164 & $83 \%$ \\
\hline UM2MC & 0.28 & 1 & 0 & $100 \%$ \\
\hline LM1C7 & 0.18 & 0.700 & 0.161 & $89 \%$ \\
\hline LM1PS & 0.54 & 0.158 & 0.091 & $52 \%$ \\
\hline LM1MT & 0.00 & 1 & 0 & $100 \%$ \\
\hline LM2PS & 0.14 & - & - & $88 \%$ \\
\hline
\end{tabular}

UI2SS: maxillary second incisor, shoveling; UI2DS: maxillary second incisor, double shoveling; UI2IG: maxillary second incisor, interruption groove; UM1CB: maxillary first molar, Carabelli's trait; UM1C5: maxillary first molar, cusp 5; UM1MC: maxillary first molar, metacone; UM2HC: maxillary second molar, hypocone; UM2MC: maxillary second molar, metacone; LM1C7: mandibular first molar, cusp 7; LM1PS: mandibular first molar, protostylid; LM1MT: mandibular first molar, trigonid crest; LM2PS: mandibular second molar, protostylid. (-) indicates a trait could not be calculated due to no variance in one observer's data.

\section{Analytical methods}

Pseudo Mahalanobis' $\mathrm{D}^{2}$ was calculated as a statistical measure of phenetic distance (Irish 2010; Konigsburg 1990) using an IML program executed through SAS 9.2 (SAS Institute 2009). Pseudo Mahalanobis $\mathrm{D}^{2}$ extends the squared Mahalanobis distance for use with dichotomized data by using a tetrachoric correlation matrix in the calculation (Konigsberg 1990). Cluster analysis and principal components of the distances were computed using PAST (Hammer et al. 2001) and used to create graphic representation of results. To test whether geographic distance was correlated with biological distance, we performed a linear regression analysis comparing the pseudo Mahalanobis $\mathrm{D}^{2}$ matrix with the distance matrix presented in Table 2 using the linear regression myfit function in $\mathrm{R}(\mathrm{R}$ Development Core Team 2012) and a Mantel test in PAST (Hammer et al. 2001).

\section{Explanatory model predictions}

We developed three simple models based on the potential sources of population structure: cultural group, geographic region, and temporal period.
Model 1: Culture group. If patterns of phenetic relationships reflect culture group, then samples attributed to each of the four regional culture groups ought to be distinct from one another. Samples from the Maya sites of Jaina Island, Yaxuna, and San Gervasio/Playa del Carmen should be phenetically closer to one another than to those from other sites. Toltec samples from Tula and Cholula should be relatively phenetically close to one another. The Mayan and Toltec samples might be relatively closer to one another than to other groups due to putative long-term trading relationships. The Mexica sample from Tlatelolco should be phenetically isolated, as should the Totonac sample from El Zapotal.

Model 2: Geographic distance. If patterns of phenetic relationships reflect geographic regions, then sites in each of the three geographic regions should be distant phenetically from samples located in other regions. Samples from the Central Mexican sites of Tula, Cholula, and Tlatelolco should possess close phenetic affinities to one another; the sample from the Veracruz site of El Zapotal ought to occupy an isolated phenetic position, while the Yucatan samples from the sites of Jaina Island, Yaxuna, and San Gervasio/Playa del Carmen should share close phenetic affinities. 
Model 3: Temporal period. If patterns of phenotypic relationships reflect time, then the sites should form two groups corresponding to Classic and Postclassic periods. The Classic sites of Cholula, El Zapotal, Tula, and Yaxuna should be relatively close. The Postclassic group should consist of Jaina Island, San Gervasio/Playa del Carmen, and Tlatelolco.

\section{Results}

\section{Biological distance}

We compared three models that would account for the patterns of inter-sample phenetic affinities. Model 1 predicted that clusters would form based on culture group; Model 2 predicted clusters would form based on geographic region; Model 3 predicted clusters reflecting time. Table 5 presents the Mahalanobis' squared distance matrix for the seven sites. The smallest biological distance is between Tula and Yaxuna; the greatest is between Tula and Tlatelolco, which may be surprising given their geographic proximity. The results of the principal components analysis (Figure 2) show a clear separation of the Mexica (Tlatelolco), Totonac (El Zapotal), and Mayan site of Jaina Island from the Toltec (Tula, Cholula) and other Mayan sites (San Gervasio/Playa del Carmen, Yaxuna) along Principal Component 1 (PC1; 94.95\% of the total variance). Principal Component 2 (PC2; 3.14\% of the total variance) separates the Mayan sites and El Zapotal from the Toltec sites and Tlatelolco. Cluster analysis (Figure 3) clusters the Toltec and two of the Mayan sites. The third Mayan site, Jaina Island, clusters most closely with Tlatelolco and Zapotal.

Comparison of the geographic distance and pseudo Mahalanobis distance matrices using

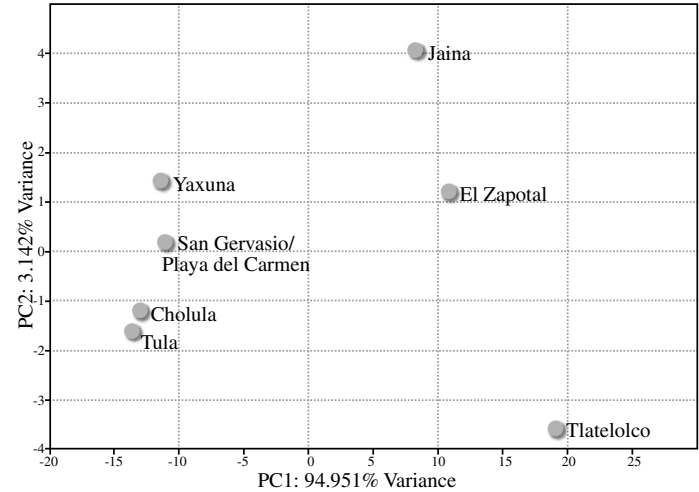

Figure 2. Results from principal components analysis; axis scales relect component weights.

Resultados de análisis de componentes principales; escalas de los ejes reflejan pesos de componentes.

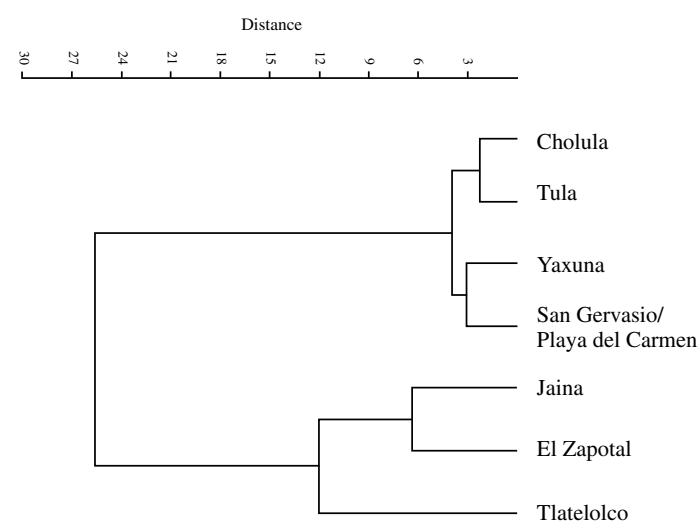

Figure 3. Results from cluster analysis.

Resultados de análisis de agrupación.

regression resulted in nonconcordance (adjusted $\mathrm{r}$ squared $=-0.02111,19$ d.f., $F=0.5865, \mathrm{p}=0.4532$ ). The Mantel test comparison of the two matrices, using 5000 random permutations, resulted in a weak positive correlation $(\mathrm{r}=0.2792, \mathrm{p}=0.1212)$. This

Table 5. Pseudo-Mahalanobis distances computed in this analysis.

Las distancias computadas de seudo-Mahalanobis en este análisis.

\begin{tabular}{|c|c|c|c|c|c|c|c|}
\hline & Tlatelolco & Jaina Island & El Zapotal & Cholula & Yaxuna & Tula & $\begin{array}{c}\text { San Gervasio/ Playa } \\
\text { del Carmen }\end{array}$ \\
\hline Tlatelolco & 0 & 1.991 & 3.525 & 15.116 & 12.548 & 15.843 & 13.754 \\
\hline Jaina Island & 1.991 & 0 & 3.182 & 7.810 & 6.986 & 9.170 & 7.364 \\
\hline El Zapotal & 3.525 & 3.182 & 0 & 11.211 & 8.675 & 9.918 & 9.086 \\
\hline Cholula & 15.116 & 7.810 & 11.211 & 0 & 0.757 & 0.759 & 1.463 \\
\hline Yaxuna & 12.548 & 6.986 & 8.675 & 0.757 & 0 & 0.535 & 1.656 \\
\hline Tula & 15.843 & 9.170 & 9.918 & 0.759 & 0.535 & 0 & 1.795 \\
\hline $\begin{array}{l}\text { San Gervasio/ Playa } \\
\text { del Carmen }\end{array}$ & 13.754 & 7.364 & 9.086 & 1.463 & 1.656 & 1.795 & 0 \\
\hline
\end{tabular}


indicates that geographic distance is not particularly predictive of biological distance (Table 5).

\section{Interobserver error}

To understand how much influence each of the traits had on the distance matrix, we performed an additional principal components analysis on a matrix of trait frequencies for each site. This calculated a trait frequency weight for each trait for each principal component (PC). To determine whether interobserver error would have skewed the distance matrix results, we performed a Pearson correlation between the calculated Cohen's kappa values and the trait frequency weights for PC1 $557.35 \%$ of the total variance) and PC2 (25.85\% of the total variance), using SPSS version 17 (2008). Cohen's kappa values v. PC1 showed a correlation of - 0.012 , $\mathrm{p}=0.973$, indicating no correlation between degree of observer concordance and trait frequency weights. Cohen's kappa values v. PC2 showed a correlation of $0.320, p=0.367$. There is a weak, but not significant correlation between degree of observer concordance and trait frequency weights. These results indicate that interobserver error is not the driving force behind the distance matrix.

\section{Discussion}

Aspects of all three models likely contribute to the overall patterning seen in the data. The results do not exactly fit any of these models, each based upon a single predictive variable. We envision this study as the first step in developing a larger set of interactive models built upon the relationship among cultural factors, geography, and biological change over relatively short periods of time. This first step, however, was necessary to determine whether patterns exist among the Maya/Toltec, Mexica, and Totonac groups that are observable through dental morphological trait analysis.

\section{Model 1: Culture group}

Model 1, which tested whether culture group best explains the patterning of phenetic affinities, is most consistent with the pseudo Mahalanobis' distance results. If Model 1 is correct, samples from the Mayan sites of Jaina Island, Yaxuna, and San Gervasio/Playa del Carmen should have close phenetic affinities; samples from the Toltec sites of Tula and Cholula ought to have close phenetic affinities, while the Mexica sample from Tlatelolco and the Totonac sample from El Zapotal should not have close affinities to one another, or to any of the other samples included in the analysis. Our principal components results indicate a broad grouping containing two of three Mayan and both Toltec samples; within the grouping, PC2 separates the those two Mayan samples from the two Toltec samples. The samples from Tlatelolco and El Zapotal are phenetically separate from the rest of the samples. Cluster analysis also links two of three Mayan and the two Toltec sites as distinct clusters, which form a larger cluster. However, the third Mayan sample, Jaina Island, does not fit the predictions of Model 1 as it clusters with El Zapotal and Tlatelolco.

We noted earlier that samples from the Mayan and Toltec sites might be relatively closer to one another than to other groups due to long-term contact. This pattern confirms the results of Aubry (2009) that central Mexico Toltec sites and Mayan samples from Yucatan sites cluster. This may support the argument that Central Mexico was involved in Maya affairs. Many archaeologists and historians argue that populations from Central Mexico were trading with populations in the Mayan region via the Gulf Coast (Cowgill 2003; Schroeder 2010; Thompson 1970). More geographically and temporally broad samples are needed to more fully explore the relationship between these two groups.

\section{Model 2: Geographic region}

The pattern does not clearly reflect Model 2, geographic region. For the pattern to be explanatory, the sample from Tlatelolco should have shared phenetic affinity with the samples from Tula and Cholula, Jaina Island with San Gervasio/Playa del Carmen and Yaxuna, and El Zapotal would be isolated. This pattern is not observed on PC1; it is violated by the locations of Tlatelolco and Jaina Island. The spread of sites along PC2 does order broadly the sites along a geographic gradient. El Zapotal, which is intermediate in distance from both Central Mexico and the Yucatan, is near the Yucatan sites along PC2. The cluster analysis spreads geographic region across both clusters. Two Yucatan and two Central Mexican sites cluster together, but one Yucatan site (Jaina Island) and one Central Mexican site (Tlatelolco) cluster with Veracruz. However, the regression analysis indicated 
no predictive relationship between the geographic distance matrix and the biological distance matrix. Therefore, this model is not the best explanation for the results.

\section{Model 3: Temporal period}

The structure seen in our results does not support Model 3, which concerns temporal periods. If temporal periods have explanatory power, samples from El Zapotal would share phenetic affinities with those from Cholula, Tula, and Yaxuna, and San Gervasio/Playa del Carmen ought to share phenetic affinities with Tlatelolco and Jaina Island. The Classic/Postclassic dichotomy is not supported by the pattern graphed by the principal components. On PC1, it is violated by the locations of El Zapotal and San Gervasio/Playa del Carmen. Additionally, the Postclassic sites spread across the range of PC2. This result is mirrored in the cluster analysis: the Classic site of El Zapotal clusters most closely with the Postclassic sites of Jaina Island and Tlatelolco, and the Postclassic site of San Gervasio/Playa del Carmen links with the rest of the Classic sites.

As stated above, our results do not perfectly reflect the predictions of any of the models. All the models have outliers that do not fit the predicted pattern. Model 1, culture group, is imperfect, but it best fits the observed pattern of biological relationships. For Model 1, only the location of Jaina Island, which was phenetically closer to El Zapotal and Tlatelolco than to the other Mayan sites, did not fit the predicted pattern. Culture group, therefore, is the strongest explanation for the source of population structure observed among these samples. More samples would allow more nuanced comparisons of results with models, such as weighting the extent to which each model explains the observed phenetic pattern.

For example, the location of Jaina Island in the cluster analysis is particularly interesting. This island is generally interpreted to be, at least in part, a burial site for Mayan elites (Lopéz Austin and Lopéz Luján 2001; Piña-Chan, 1968), although it was also heavily involved in coastal trade between the Gulf Coast and the Yucatan (Benavides Castillo 2001, 2007). The relatively small biodistance between Jaina Island and the Mexica site of Tlatelolco raises the possibility that some of the people buried at this Postclassic level of Jaina Island might have some Mexica ancestry. This possibility was raised by
Pompa y Padilla (1984); in a comparison of samples from Chichén Itzá, Jaina Island, and Tlateloloco, Jaina Island and Tlatelolco had similar frequencies on some traits, distinct from Chichén Itzá. Jaina Island and El Zapotal are both sites on the Gulf of Mexico, and both were participating in coastal trade (Benavides Castillo 2001; Diehl 2000). Future analysis of temporal intrasite variability at Jaina Island, and comparisons to additional Mayan, Totonac and Mexica samples may shed light on this issue.

Since the elaborate ethnohistorical and archaeological records of pre-contact Mexico reflect extraordinarily complex migration patterns occurring in a relatively small geographic area over an evolutionarily brief period, we were concerned about potential difficulty in detecting differences between groups, even at this broad scale, and with relatively small samples. A significant finding of this research is to distinguish patterns among the Maya/Toltec, Mexica, and Totonac groups through dental morphological trait analysis. That these groups are distinct at this broad level of analysis is heartening for future work on tracing past migration patterns. Testing for trait patterning at this level is a necessary step before deepening analysis to include more sites, regions, and temporal periods. Many more samples from a variety of cultural groups, geographic regions, and temporal periods are needed to determine whether the broad cultural group patterns seen here are maintained at a finer grain of analysis.

These results reinforce the findings of Ullinger and colleagues (2005) and Vargiu and colleagues (2009), that indicate the effectiveness of dental morphological traits analysis to detect local population differences, here specifically in Mexico. We think Mexico has a complex migration history because we know much about its past from decades of detailed ethnohistoric and archaeological research. However, while the record is more detailed for Mexico, there is no reason to suppose that the migration history is more complex there than in many other areas of the world where biological distance studies have been informative. While more samples are needed from different regions and temporal periods, this research demonstrates the potential for deepening our understanding of the population history of preEuropean contact Mexican groups, and will provide an additional line of evidence to test hypotheses of population movement and admixture in relationship to the archaeological record. 
Acknowledgements: We thank Mtro. José Antonio Pompa y Padilla at the Instituto Nacional de Antropología e Historía, Mexico City and Dr. Arias Lopez at the Instituto Nacional de Antropología e Historía, Yucatan, for permitting access to the Museum's collections. David Volcanes Vidal and Irma Martinez Chavez provided invaluable assistance at the Museo Nacional de Antropología, Mexico City. Cameron Griffith, Christopher Ruff, and several anonymous reviewers provided helpful comments on earlier versions of this manuscript. This research was sponsored by Central Michigan University, Faculty Research and Creative Endeavors, Grant number: 48821; National Science Foundation, Dissertation Improvement Grant, Grant number: 0550902; Ohio State University Center for Latin American Studies, Tinker Field Research Grant; Ohio State University Alumni Grant for Graduate Research.

\section{References Cited}

Aubry, B.S. 2009. Population Structure and Interregional Interaction in Prehispanic Mesoamerica: A Biodistance Study. Doctoral Dissertation, Department of Anthropology, The Ohio State University, Columbus.

Benavides Castillo, A. 2001. Jaina. In Oxford Encyclopedia of Mesoamerican Cultures, Volume 2, edited by D. Carrasco, pp. 68-69. Oxford University Press, Oxford.

- _ _ 2007. Jaina en el contexto de las poblaciones del Clásico en el occidente peninsular. In La Población Prehispánica de Jaina: Estudio Osteobiográfico de 106 Esqueletos, edited by P. Hernández and L. Márquez Morfín, pp. 13-31. Instituto Nacional de Antropología e Historia, Cuauhtémoc, México, D.F.

Berdan, F.F. 2008. Concepts of ethnicity and class in Aztec-period Mexico. In Ethnic Identity in Nahua Mesoamerica: The View from Archaeology, Art History, Ethnohistory, and Contemporary Ethnography, edited by F.F. Berdan, J.K. Chance, A.R. Sandstrom, B.L. Stark, J.M. Taggart, and E. Umberger, pp. 105-132. The University of Utah Press, Salt Lake City.

Brotherston, G. 2001. Tollan. In Oxford Encyclopedia of Mesoamerican Cultures, Volume 3, edited by D. Carrasco, pp. 236-239. Oxford University Press, Oxford.

Campbell, L. 2004. Historical Linguistics: An Introduction. Second edition, Edinburgh University Press, Edinburgh.

Campbell, L. and T. Kaufman 1985. Mayan linguistics: where are we now? Annual Review of Anthropology 14:187-198.

Cobean, R.H. and A.G. Mastache 2001. Toltec. In Oxford Encyclopedia of Mesoamerican Cultures, Volume 3, edited by D. Carrasco, pp. 239-241. Oxford University Press, Oxford.

Colunga-García Marín, P. and D. Zizumbo-Villarreal 2004. Domestication of plants in Maya lowlands. Economic Botany 58:S101-S110.

Coppa, A., A. Cucina, D. Mancinelli, R. Vargiu and J.M. Calcagno 1998. Dental anthropology of Central-Southern, Iron Age Italy: the evidence of metric versus nonmetric traits. American Journal of Physical Anthropology 107:371-386.

Cowgill, G.L. 2000. The central Mexican highlands from the rise of Teotihuacan to the decline of Tula. In The Cambridge History of the Native Peoples of the Americas, Volume 2: Mesoamerica, Part 1, edited by R.E.W. Adams and M.J. MacLeod, pp. 250-317. Cambridge University Press, Cambridge.
_. _ 2003. Teotihuacan and Early Classic interaction: A perspective from outside the Maya region. In The Maya and Teotihuacan: Reinterpreting Early Classic Interaction, edited by G.E. Braswell, pp. 315-335. University of Texas Press, Austin.

Cucina, A. and V. Tiesler Blos 2004. Dental morphometry and biological affinity in pre-contact and contact Maya populations from the peninsula of Yucatan. Mexicon 26:14-19.

Culbert, T.P. 1991. Classic Maya Political History: Hieroglyphic and Archaeological Evidence. Cambridge University Press, Cambridge.

Dahlberg, A.A. 1951. The dentition of the American Indian. In Papers on the Physical Anthropology of the American Indian, edited by W.S. Laughlin, pp. 138-176. The Viking Fund, New York.

Daneels, A. 1997. Settlement history in the lower Cotaxtla basin. In Olmec to Aztec: Settlement Patterns in the Ancient Gulf Lowlands, edited by B.L. Stark and P.J. Arnold III, pp. 206-252. The University of Arizona Press, Tucson.

Davies, N. 1980. The Toltec Heritage: From the Fall of Tula to the Rise of Tenochtitlan. University of Oklahoma Press, Norman.

Davies, N. 1987. The Toltecs: Until the Fall of Tula. University of Oklahoma Press, Norman.

De Lourdes Muñoz, M., E. Ramos, A. Díaz-Badillo; M.C. MoralesGómez, R. Gómez, and G. Pérez-Ramírez 2012. Migration of pre-Hispanic and contemporary human Mexican populations. In Causes and Consequences of Human Migration, edited by M.H. Crawford and B.C. Campbell, pp. 417-435. Cambridge University Press, Cambridge.

Diehl, R.A. 1983. Tula: the Toltec Capital of Ancient Mexico. Thames and Hudson, London.

_ _ _ 2000. The Precolumbian cultures of the Gulf Coast. In The Cambridge History of the Native Peoples of the Americas, Volume 2: Mesoamerica, Part 1, edited by R.E.W. Adams and M.J. MacLeod, pp. 156-196. Cambridge University Press, Cambridge.

Edgar, H.J.H. 2007. Dental morphology and the microevolution of African Americans. American Journal of Physical Anthropology 132:535-544.

Evans, S.T. 2013. Ancient Mexico and Central America: Archaeology and Culture History. Third Edition. Thames and Hudson, London. 
Google Earth Software 2012. Version 6. Google, Inc., Mountain View, CA. http://www.google.com.earth.index.html (January 24, 2012).

GraphPad Software, Inc. 2005. http://graphpad.com/quickcalcs/ kappa1.cfm (January 24, 2012).

Greenberg, J.H., C.G. Turner II and S.L. Zegura 1986. The settlement of the Americas: a comparison of the linguistic, dental, and genetic evidence [with comments and reply]. Current Anthropology 27:477-497.

Grove, D.C. 2000. The preclassic societies of the central highlands of Mesoamerica. In The Cambridge History of the Native Peoples of the Americas, Volume 2: Mesoamerica, Part 1, edited by R.E.W. Adams and M.J. MacLeod, pp. 122-155. Cambridge University Press, Cambridge.

Haeussler, A.M., J.D. Irish, D.H. Morris and C.G. Turner II 1989 Morphological and metrical comparison of San and central Sotho dentition from southern Africa. American Journal of Physical Anthropology 78:115-122.

Hammer, Ø, D.A.T. Harper and P.D. Ryan 2001. PAST: paleontological statistics software package for education and data analysis. Palaeontologia Electronica 4(1):9. http://palaeoelectronica.org/2001_1/past/issue1_01.htm.

Hammond, N. 1986. The emergence of Maya civilization. Scientific American 255:106-115.

. _ _ 2000. The Maya lowlands: pioneer farmers to merchant princes. In The Cambridge History of the Native Peoples of the Americas, Volume 2: Mesoamerica, Part 1, edited by R.E.W. Adams and M.J. MacLeod, pp. 197-249. Cambridge University Press, Cambridge.

Hanihara, K. 1967. Racial characteristics in the dentition. Journal of Dental Research 46:923-926.

Hassig, R. 2010. The collision of two worlds. In The Oxford History of Mexico, edited by W.H. Beezley and M.C. Meyer, pp. 73-107. Oxford University Press, Oxford.

Haydenblit, R. 1996. Dental variation among four prehispanic Mexican populations. American Journal of Physical Anthropology 100:225-246.

Hicks, F. 2008. Mexica political history. In The Aztec World, edited by E.M. Brumfiel and G.M. Feinman, pp. 5-21. Abrams Press, New York.

Hillson, S. 1996. Dental anthropology. Cambridge University Press, Cambridge.

Irish, J.D. 1993. Biological Affinities of Late Pleistocene Through Modern African Aboriginal Populations. Doctoral Dissertation, Department of Anthropology, Arizona State University, Tempe.

- _ _ 2005. Population continuity vs. discontinuity revisited: dental affinities among Late Paleolithic through Christian-era Nubians. American Journal of Physical Anthropology 128:520-535.

_ _ _ 2010. The mean measure of divergence: its utility in modelfree and model-bound analyses relative to the Mahalanobis $\mathrm{D}^{2}$ distance for nonmetric traits. American Journal for Human Biology 22:378-395.

Irish, J.D. and C.G. Turner II 1990. West African dental affinity of late Pleistocene Nubians: peopling of the Eurafrican-South Asian triangle II. Homo 41:42-53.
Jackes, M., A.M. Silva and J. Irish 2001. Dental morphology: a valuable contribution to our understanding of prehistory. Journal of Iberian Archaeology 3:97-119.

Jones, L. 1997. Conquests of the imagination: Maya-Mexican polarity and the story of Chichén Itzá. American Anthropologist 99:275-290.

Konigsburg, L.W. 1990. Analysis of prehistoric biological variation under a model of isolation by geographic and temporal distance. Human Biology 62:49-70.

Larsen, C.S. 1997. Bioarchaeology: Interpreting Behavior from the Human Skeleton. Cambridge University Press, Cambridge.

Larsen, C.S. and M.A. Kelley 1991. Introduction. In Advances in Dental Anthropology, edited by M.A. Kelley and C.S. Larsen, pp. 1-7. Wiley-Liss, New York.

Lewis, M.P. (ed.) 2009. Ethnologue: Languages of the World, $16^{\text {th }}$ edition, SIL International, Dallas. Online version: http:// www.ethnologue.com (September 9, 2011).

Lukacs, J.R. and B.E. Hemphill 1991. The dental anthropology of prehistoric Baluchistan: a morphometric approach to the peopling of South Asia. In Advances in Dental Anthropology, edited by M.A. Kelley and C.S. Larsen, pp. 77-119. Wiley-Liss, New York.

Lopéz Austin, A. and L. Lopéz Luján 2001. Mexico’s Indigenous Past. Norman, OK: University of Oklahoma Press.

- _ _ 2008. Aztec human sacrifice. In The Aztec World, edited by E.M. Brumfiel and G.M. Feinman, pp. 137-152. Abrams Press, New York.

Marcus, J. 1976. The origins of Mesoamerican writing. Annual Review of Anthropology 5:35-67.

Masson, M.M. and S.B. Mock 2004. Ceramics and settlement patterns at Terminal Classic-period lagoon sites in northeastern Belize. In The Terminal Classic in the Maya Lowlands: Collapse, Transition, and Transformation, edited by A.A. Demarest, P.M. Rice and D.S. Rice, pp. 367-401. University Press of Colorado, Boulder.

McVicker, D. 1985. The "Mayanized" Mexicans. American Antiquity 50:82-101.

Ochoa, L. 2001. Gulf Coast. In Oxford Encyclopedia of Mesoamerican Cultures, Volume 1, edited by D. Carrasco, pp. 448-451. Oxford University Press, Oxford.

Piña-Chan, R. 1968. Jaina: la Casa en el Agua. Instituto Nacional de Antropología e Historia, México, D.F.

Pohl, M.D., K.O. Pope, J.G. Jones, J.S. Jacob, D.R. Piperno, S.D. deFrance, D.L. Lentz, J.A. Gifford, M.E. Danforth and J.K. Josserand 1996. Early agriculture in the Maya lowlands. Latin American Antiquity 7:355-372.

Pompa y Padilla, J.A. 1984. Jaina y Chichén Itzá: morfología dentaria normal de dos muestras de la población maya prehispánica. Memorias de la XVII mesa redonda de la Sociedad Mexicana de Antropología. 2:481-489. Sociedad Mexicana de Antropología, San Cristóbal de las Casas.

- _ _ 1990. Antropología Dental: Aplicación en Poblaciones Prehispánicas. Serie Antropología Física, Instituto Nacional de Antropología e Historia, México, D.F.

- _ _ 1996. Estudios de antropología dental en México. La antropología física en México: Estudios sobre la población 
antigua y contemporánea, IIA, pp. 171-181, Universidad Autónoma de México.

R Development Core Team 2012. A language and environment for statistical computing. Vienna, Austria: R Foundation for Statistical Computing. http://www.R-project.org.

SAS Institute 2009. http://support.sas.com/software/92.

Scherer, A. 2004. Dental Analysis of Classic Period Population Variability in the Maya Area. Doctoral Dissertation, Department of Anthropology. Texas A\&M University, College Station.

_ _ _ 2007. Population structure of the Classic period Maya. American Journal of Physical Anthropology 132:367-380.

Schortman, E. and P. Urban 2001. Interregional interactions. In Archaeology of Ancient Mexico and Central America: an Encyclopedia, edited by S.T. Evans and D.L. Webster, pp. 365371. Garland Publishing, Inc., New York.

Schroeder, S. 2010. The Mexico that Spain encountered. In The Oxford History of Mexico, edited by W.H. Beezley and M.C. Meyer, pp. 45-72. Oxford University Press, Oxford.

Scott, G.R. 1973. Dental Morphology: A Genetic Study of American White Families and Variation in Living Southwest Indians. Doctoral Dissertation, Department of Anthropology, Arizona State University, Tempe.

Scott, G.R. and C.G. Turner II 1988. Dental anthropology. Annual Review of Anthropology 17:99-126.

_ _ _ 1997. The Anthropology of Modern Human Teeth: Dental Morphology and its Variation in Recent Human Populations. Cambridge University Press, Cambridge.

Smith, M.E. 1984. The Aztlan migrations of the Nahuatl chronicles: myth or history? Ethnohistory 31:153-186.

_. _ - 2008. The Aztec empire. In The Aztec World, edited by E.M. Brumfiel and G.M. Feinman, pp. 121-136. Abrams Press, New York.

SPSS 2008. SPSS Statistics Base 17.0. SPSS Inc., Chicago.

Stark, B.L. 1978. An ethnohistoric model for native economy and settlement patterns in Southern Veracruz, Mexico. In Prehistoric Coastal Adaptations: the Economy and Ecology of Maritime Middle America, edited by B.L. Stark and B. Voorhies, pp. 211-238. Academic Press, New York.
Stark, B.L and P.J. Arnold III 1997. Introduction to the archaeology of the Gulf lowlands. In Olmec to Aztec: Settlement Patterns in the Ancient Gulf Lowlands, edited by B.L. Stark and P.J. Arnold III, pp. 3-32. The University of Arizona Press, Tucson.

Thompson, J.E.S. 1970. Maya History and Religion. University of Oklahoma Press, Norman.

Turner, C.G. II 1987. Late Pleistocene and Holocene population history of East Asia based on dental variation. American Journal of Physical Anthropology 73:305-322.

_ _ _ 1990. Major features of sundadonty and sinodonty, including suggestions about East Asian microevolution, population history, and Late Pleistocene relationships with Australian aboriginals. American Journal of Physical Anthropology 82:295-318.

_ _ _ 1992. The dental bridge between Australia and Asia: following Macintosh into the East Asian hearth of humanity. Perspectives on Human Biolology 2/Archaeology of Oceania 27:120-127.

Turner, C.G. II, C.R. Nichol and G.R. Scott 1991. Scoring procedures for key morphological traits of the permanent dentition: the Arizona State University dental anthropology system. In Advances in Dental Anthropology, edited by M.A. Kelley and C.S. Larsen, pp. 13-31. Wiley-Liss, New York.

Ullinger, J.M., S.G. Sheridan, D.E. Hawkey and C.G. Turner II 2005. Bioarchaeological analysis of cultural transition in the southern Levant using dental morphological traits. American Journal of Physical Anthropology 128:46-476.

Vargiu, R, A. Cucina and A. Coppa 2009. Italian populations during the Copper Age: assessment of biological affinities through morphological dental traits. Human Biology 81:479-493.

Weaver, M.P. 1972. The Aztecs, Maya, and Their Predecessors: Archaeology of Mesoamerica. Seminar Press, New York.

- _ _ 1993. The Aztecs, Maya, and Their Predecessors. Third edition. Academic Press, San Diego.

Willermet, C.M. and H.J.H. Edgar 2009. Dental morphology and ancestry in Albuquerque, NM Hispanics. Homo 60:207-224.

Wrobel, G.D. 2003. Metric and Nonmetric Dental Variation Among the Ancient Maya of Northern Belize. Doctoral Dissertation, Department of Anthropology. University of Indiana, Bloomington. 
